\title{
Sheehan 症候群の内分泌学的検討
}

\author{
岡山大学医学部第三内科（主任：大藤 道教授） \\ 浅岡克司
}

(昭和52年 8 月 23 日受稿)

\section{I 緒言}

1937年 Sheehan が分婏時の出血並びに, shock 后 におてる下垂体機能低下症について詳細に報告”し て以后, 分婏時の障害に上る下垂体前葉機能低下症 は分婏以外でおこる下垂体機能低下症とは区別して Sheehan's syndrome と呼ばれるようになった?! の后, Sheehan 症候群の概念は広く行きわたってお り，現在までに数多くの症例か報告されている．し かるにそれらの報告の多くは必ずしも内分泌機能検 查が充分に行われているとは云えず, Sheehan 症候 群の下垂体前葉機能の詳細については充分明かにな っているとは云えない面がある. 他方, 最近の内分 泌学の進歩により, 血中の下垂体ホルモンの測定及 び視床下部ホルモンの臨床忍用が可能となり，下垂 体ホルモン分祕趽態が正確に把握出来るようになっ てきた.こうした現状において著者は, Sheehan症 候群の内分䎵機能について再検討することは意義が あると考元，8例のSheehan 症候群患者について， 主として内分化機能を中心として検討し，興味ある 結果をえたので報告する.

\section{II 対 象}

著者が体験した 8 例の Sheehan 症候群患者は, Tablel に示す如くむろん全例女性で, 入院時年令は 32才から60才にわたっており，平均は43才であった。 8例のうち7例は, 出産時の大出血並びに shock te 契機として下垂体機能不全症状を呈してきたと思わ れたが，残り1例は帝王切開后， 1 週間の発熱が続 き, 徐々に下垂体機能不全を呈したと考えられる例 であった. (Table 1, Table 2)

$$
\text { III 方 法 }
$$

(1)視床下部一下垂体一副腎皮質予備能については， 著者らの教室で行っている簡易視床下部下垂体副腎 機能検查 (Short hypothalamo-hypophyseo-adr- enocortical function test, SHAFT (略す) 辛を施 行した．第 1 日目に午前 9 時, 午后 4 時と午后11時 に血獎 cortisol 值を測定し cortisol の日内変動を 観察し,さらに午后11時に dexamethasone $1 \mathrm{mg}$ を 経口投与し， 2 日目の朝 9 時㲹採血, single dose dexamethasone test とし，その后 regular insulin $0.1 \mathrm{u} / \mathrm{kg}$ を静往, 30 分， 60 分，90分と採血した. 2 日目の年后11時に再度 dexamethasone $1 \mathrm{mg}$ を経口 投与し, 翌 3 日目の朝 9 時に採血后, $\beta 1$ - $24 \mathrm{ACTH}$ $0.25 \mathrm{mg}$ 老静注し, 30 分, 60 分之採血し血墏 cortisol 値を測定した. 以上 3 日間で血漿 cortisol の日内変 動, 視床下部下垂体刺激試験, overnight dexamethasone suppression test，副腎皮質刺激試験を 施行した, 又一部の症例では, Lysine- 8·vasopressin(LVP) 4 単位静注による LVP test を施行し た。 さらに $3 \mathrm{~g}$ 経口投与による metopirone test 並 びに ACTH-Z 0.5mg 3 日間筋注法による ACTH-Z test 施行し，尿中17-KGS 值を測定した. 尚, 血 漿 cortisol 值は Clark の変法", 一部radioimmunoassay にて測定し，尿中17-KGS 值は神戸川法にて 測定した.

(2)成長ホルモン (HGH) 分跅予備能については, insulin test t行った. regular insulin $0.1 \mathrm{u} / \mathrm{kg} の$ 静注負荷后, 30分, 60分, 90分任採血し, 血漿 $\mathrm{HGH}$ 値を測定した，尚，血漿 $\mathrm{HGH}$ 值は二抗体法による radioimmunoassayにて測定した:

(3)視床下部一下垂体一性腺系予備能については, LHRH test を施行した. 合成 LHRH $100 \mu \mathrm{g}$ を生理 食塩水 $10 \mathrm{ml}$ に溶解し静注した。採血は静注前, 静注 后15分, 30分, 45分, 60分, 90 分に行い, 血漿 $\mathrm{LH}$ 並びに FSH値を測定した，血漿 LH，FSH值は二 抗体法に上る radioimmunoassay にて測定した. (4)視床下部一下垂体一甲状腺系予備能については, TRH負荷試験を施行した. TRH test は合成 TRH $500 \mu \mathrm{g}$ を $10 \mathrm{ml}$ の生理食塩水に溶解し静脈内に注射 し, 注射前及び注射后15分，30分，45分，60分，90 
Table 1 Obstetrical history of 8 cases with Sheehan!s syndrome

\begin{tabular}{|c|c|c|c|c|c|c|c|c|}
\hline case & $1 Y, Y$. & $2 \mathrm{~K} . \mathrm{T}$. & 3 K. H. & 4 N. K. & 5 H. 0. & 6 M. T. & 7 K. S. & 8 T. I. \\
\hline age at admission & 40 & 33 & 37 & 56 & 32 & 60 & 40 & 47 \\
\hline para & 1 & 1 & 1 & 5 & 1 & 2 & 1 & 3. \\
\hline $\begin{array}{l}\text { severity of postpartum } \\
\text { hemorrhage }\end{array}$ & $(-)$ & $500 \mathrm{ml}$ & $(+H)$ & $(+)$ & 1200 & $(+)$ & $(+)$ & (H) \\
\hline shock & $(-)$ & $(+1)$ & $(+\#)$ & $?$ & $(+\ldots)$ & $(-)$ & $(-)$ & $(+\#)$ \\
\hline blood transfusion & $(-)$ & $200 \mathrm{ml}$ & $(+)$ & $(-)$ & $(-)$ & $(-)$ & $(-)$ & $(-)$ \\
\hline place of delivery & $\begin{array}{c}\text { local } \\
\text { hospital }\end{array}$ & home & $\begin{array}{c}\text { maternity } \\
\text { home }\end{array}$ & home & $?$ & $\begin{array}{c}\text { local } \\
\text { hospital }\end{array}$ & $\begin{array}{c}\text { local } \\
\text { hospital }\end{array}$ & $?$ \\
\hline $\begin{array}{c}\text { duration at onset of } \\
\text { disease }\end{array}$ & $2^{\text {years }}$ & 6 & 11 & $?$ & 3 & 15 & 1.5 & 8 \\
\hline
\end{tabular}

分及び120分に採血し, 血墏 TSH 值を測定した. 又， 血中 $\mathrm{T}_{3}$-resine sponge uptake 值 (以下 $\mathrm{T}_{3}-\mathrm{RSU}$ と 略す）及び thyroxine 值（以下 $\mathrm{T}$ 、と略す）も測定し た. 尚，血中 $T_{3}-R S U$ 値は $T$ riosorb，血中 $T_{\text {值は }}$ Tetrasorh及びRes-O-mat T،にて測定した。血 漿 TSH值は二抗体法による radioimmunoassayに て测定した.

(5) prolactin 分泌予備能については，前述の TRH $500 \mu \mathrm{g}$ 静注前, 静注后 15 分, 30 分, 45分, 60 分, 90 分の血漿 prolactin 值を測定した. 血漿 prolactin 值 は二抗体法によろ radioimmuuoassay にて測定した。 (6)一般臨床検查については, 各症例毎に, 検血, 血 沈, 電解質, コレステロール, 総蛋白, 蛋白分画, 血糖，GOT，GPT等を Table 3 に概略した。

\section{IV 結 果}

1. 病歷並びに臨床症状では, Table 1, Table 2 に 示すように, Y, Y, 例で大出血並びにショックを契 機とせず下垂体機能低下症を呈してきた事は興味深 い点である. 又，輸血については，8例中 2 例のみ が輸血を受けているに過ぎなかっだ：出産場所は， 1 例が助産院，2例が自宅分婏であった，症状の発 現年数は1.5年から15年と期間は長期にわたった。 尚, N.K. 例では, 大出血並びに shock $の$ episode 以后 4 人の出産を経験していたことも興味深い点で あった．臨床症状では，寒玲抵抗減㢭，動作緩慢， 意篎高失, 皮虐荅白を, 又乳汁分泌不全, 腋毛並び に职毛脱毛の訴えが多く認められた．月経について は, 3例の患者は, episode 以后月䅅があったと述 ベている.

2.一般臨床血液検査では,多くの症例においては, 血液一般で低色素性貧血と相対的リンパ球の増加が 認められた， 1 時間値の血沈も元進していた. 血中
電解質では $135 \mathrm{mEq} / \mathrm{L}$ 以下の低ナトリウム血症を呈 した症例が3例も認められた. 又高コレステロール 血症も 4 例に認められた. 栄腹時血糖については著 しい低血糖を示したものは認められなかった。肝機 能検查においてはGOT, GPT值が共に高い例が3 例諗められた。

3. 内分泌機能

1 ）視床下部一下垂体一副腎皮質系予備能検查では, Table 4, Fig. 1, Fig. 2のどとく, K, H., H. O. の 2 症例では，血漿 cortisol の日内変動は正常な patternを, 又, insulin testでは, 低反応ながら增 加反応が認められた. 一方, K. S., T. I., Y. Y., M. T. の4症例は, 血獎 cortisol 值の基礎値は低值 を示し,さらに, insuliu test並びに raqid ACTH test では, 血槳 cortisol の反応は低反応ないしは 無反応を示した. 又, K. T. 例は, LVP test を施 行した. 負荷前血獎 cortisol 值は2.4 $\mu \mathrm{g} / \mathrm{dl}$, 負荷 后 15 分 $5.0 ， 30$ 分 $3.9,60$ 分 3.6 と低反応を示した. metopirone test では施行例 6 例全例が無反応を示 した. 又, $\mathrm{ACTH}-\mathrm{Z}$ testでも施行例全例が低反応 ないし無反応を示した. 尚, M.T.はhydrocortisone $10 \mathrm{mg} /$ day rocortis one $80 \mathrm{mg}$ を, 又, N.K. は中状腺末 $30 \mathrm{mg}$ を毎日内服中であった．以上の結果により，K. H., H. O. を除いた他の 6 例においては下垂体一副腎皮 質系機能の低下が推定された。

2) 成長ホルモン分泌予備能については, Y.Y., K. H., H. O., M. T., K. S., T. I. の6 症例につい て検討をした. (Table 4, Fig. 3) Y.Y. 例のみ がinsulin induced hypoglycemia に対して血漿 HGH は正常反応を呈した以外は, 他の5 例では全て反応 がみられなかった. 尚, M. T. 例はhydrocortisone $10 \mathrm{mg} /$ day を内服中であった. 
Table 2 Clinical features in 8 cases with Sheehan's syndrome

\begin{tabular}{|l|c|c|c|c|c|c|c|c|}
\hline \multicolumn{1}{|c|}{ Symptom } & Y. Y. & K. T. & K. H. & N. K. & H. O. & M. T. & K. S. & T. I. \\
\hline dizziness & $?$ & - & + & $?$ & + & $?$ & + & + \\
\hline gastrointestinal disturbance & + & - & - & + & + & - & + & - \\
\hline cold intolerance & + & + & + & + & $?$ & + & + & + \\
\hline atrophy of breasts & $?$ & - & - & $?$ & $?$ & $?$ & - & - \\
\hline amnesia & $?$ & - & + & $?$ & $?$ & + & + & - \\
\hline disturbance of consciousness & + & - & + & $?$ & $?$ & + & + & + \\
\hline hypogalactia & + & + & + & + & $?$ & $?$ & + & + \\
\hline hyposexuality & $?$ & - & - & $?$ & $?$ & $?$ & + & + \\
\hline dry skin & + & + & + & $?$ & $?$ & - & + & - \\
\hline hypopraxia & + & + & + & + & + & + & + & + \\
\hline senile countenance & $?$ & - & - & $?$ & $?$ & $?$ & + & + \\
\hline sterility & + & + & + & - & + & + & + & + \\
\hline polyuria & + & - & - & - & $?$ & - & + & - \\
\hline loss of hair of eyebrows & $?$ & + & + & - & $?$ & $?$ & + & + \\
\hline pallor & + & + & + & $?$ & $?$ & + & + & + \\
\hline slackness & + & + & + & + & + & + & + & + \\
\hline loss of pubic hair & + & + & + & + & + & + & + & - \\
\hline loss of axilary hair & + & + & + & + & + & + & + & - \\
\hline cramp & + & - & - & $?$ & $?$ & - & - & - \\
\hline hypohidrosis & $?$ & - & - & $?$ & $?$ & $?$ & + & + \\
\hline depigmentation & $?$ & - & - & $?$ & $?$ & $?$ & - & + \\
\hline amenorrhea & - & + & + & - & - & + & + & + \\
\hline
\end{tabular}

gastrointestinal disturbance is nausea, diarrhea, vomiting and constipation

3) 視床下部一下垂体一性腺系検査については, Table 4, Fig. 4 亿示した. 血漿LHについては, M. T. 例は基礎值並びに LHRH test の反応も低く， K. S., N. K., K. H. の 3 例は LH の基礎值は正常 範囲にあるが，LHRH に対するLHの反応は低 反応であった，K．T. 例では，LHの基礎值は高い が, LHRH に対する LH の反応は低かった. 又, T. I. 例は LH の基礎值は正常範囲であるが，LHRHに対 するLHの反応は遅延型であった．血漿FSHにつ いては，K.S., M.T. の2 例では基礎值も LHRH に対する反応も低下していた．K.H．は基礎值は正 常範围にあるが，LHRHに対するFSHの反応は低 反応を示した．又，T.I.と N. K. 例では遅延反応 を呈した．K. T. では基礎值は高く, 又 LHRH に対 する FSHの反応は正常反応であった. 尚，N.K. は hydrocortisone $10 \mathrm{mg}$ 之甲状腺末 $40 \mathrm{mg}$ を，M. T. は hydrocortisone $10 \mathrm{mg}$, T. I. は甲状腺末 $30 \mathrm{mg}$ 毎日内服中であった.

4) 視床下部一下垂体一甲状腺系機能検査成績は Ta ble 4及び Fig. 5 に示した. 血中 $T_{3}-R S U$ 值は M. T. 以外は全例低く，血中 T值は，H. O., Y. Y., M. T. の3例で正常の下界を呈していた，血漿 TSH值に
ついては，TRH負荷試験で5例全例低反応で, 視床 下部一下垂体一甲状腺系の障害を示晙していた. 尚, M. T. 例は, 入院前 hydrocortisone $15 \mathrm{mg}$ と thy $\mathrm{r}$ $\operatorname{adin} \mathrm{S} 150 \gamma$ 毎日内服, 入院后検査時 hydrocortisone $10 \mathrm{mg} /$ day ぬ内服中であった。

5) prolactin分泌予備能は, K. S., T. I., K. T. の3例について TRH test 時のprolactinの反応性 を検討したが，3例とも低反応であった。

$$
\mathrm{V} \text { 考按 }
$$

Sheehan 症候群 8 例について出来るだけ詳細な下 垂体前葉機能の検討をおこなった．視床下部一下垂 体一副腎皮質予備能については, insulin負荷で血 漿 cortisol の軽度の堌加があるにもかかからず metopirone test で尿中17-KGSの反応がない2 例か䞏 められたこのdiscrepancyについて以下の事が考 えられる。

(1) 甲状腺機能低下のため血獎 cortis ol の代謝が障 害されており, さらに㻉のクリアランスが減少して いるととにより steroidの排泄か浙制されているた め血漿 cortisol と尿中17-KGS の反応の間の discrepancy が起った可能性が考えられる!(2)視床下部 
Table 3 Laboratory data at admission

\begin{tabular}{|c|c|c|c|c|c|c|c|c|}
\hline & $1 Y . Y$. & $2 \mathrm{~K} . \mathrm{T}$. & 3 K. H. & $4 \quad$ N. K. & $5 \mathrm{H.} \mathrm{O}$. & 6 M. T. & $7 \quad$ K. S. & 8 T. I. \\
\hline $\begin{array}{c}\mathrm{RBC} \\
104 / \mathrm{mm}^{3}\end{array}$ & 385 & 324 & 301 & 365 & 374 & 411 & 425 & 320 \\
\hline $\begin{array}{l}\mathrm{Hgb} . \\
\%\end{array}$ & 80 & 55 & 52 & 61 & 56 & 75 & 73 & 68 \\
\hline $\begin{array}{c}\text { Lym. } \\
\%\end{array}$ & 67 & 48 & 36 & 22 & 42 & 51 & 19 & 72 \\
\hline $\begin{array}{l}\text { Sed. rate } \\
\mathrm{mm} \\
\text { in } \mathrm{hr} .\end{array}$ & 13 & 22 & 12 & 22 & 47 & 26 & 50 & 37 \\
\hline $\begin{array}{c}\mathrm{Na} \\
\mathrm{mEq} / \mathrm{L}\end{array}$ & 125 & 116 & 132.8 & 145 & 140.6 & 136 & 124.5 & 136 \\
\hline $\begin{array}{l}2 \\
4 \\
0\end{array}$ & 4.2 & 3.9 & 3.9 & 5.4 & 5.0 & 4.5 & 3.4 & 3.8 \\
\hline $\begin{array}{c}\mathrm{Fe} \\
\gamma / \mathrm{dL}\end{array}$ & 57 & 69 & 112 & 108 & & 81 & 65 & 92 \\
\hline $\begin{array}{l}\text { Chol. } \\
\mathrm{mg} / \mathrm{dL}\end{array}$ & 116 & 295 & 242 & 171 & 173.8 & 279 & 263 & 234 \\
\hline $\begin{array}{l}\text { Total } \\
\text { prot. } \\
\mathrm{g} / \mathrm{dL}\end{array}$ & 6.8 & 6.8 & 7.7 & 6.4 & 6.5 & 7.4 & 7.0 & 6.6 \\
\hline $\begin{array}{l}A / G \\
\text { ratio }\end{array}$ & 1.90 & 1.38 & 1.62 & 2.50 & 1.53 & 1.55 & 1.44 & 1.0 \\
\hline $\begin{array}{l}\text { Blood } \\
\text { Sugar } \\
\mathrm{mg} / \mathrm{dL}\end{array}$ & 76 & 64.6 & 88 & 87 & 59 & 88 & 90 & 108 \\
\hline $\begin{array}{l}\text { GOT } \\
\text { unit }\end{array}$ & 20 & 135 & 42 & 88 & 25.5 & 17 & 25 & 33 \\
\hline $\begin{array}{l}\text { GPT } \\
\text { unit }\end{array}$ & 8 & 49 & 35 & 81 & 5 & 7 & 9 & 15 \\
\hline
\end{tabular}

$\mathrm{RBC}=$ erythrocytes chol. $=$ cholesterol

hemoglobin

Lym. $=$ lymphocytes

Sed. rate $=$ Sedimentation rate

下垂体の障害の程度によって insuIin tes $\mathrm{t}$ 反応し ulin 低血糖に対する反応は metpirone にくらへて ても metopirone testに反応しない状態が考えられ ろ. 勝木らのは下垂体色素嫌性腺腫例で metopirone 侵され難く，すなわち下垂体の最終的予備能を表わ すものと推定している.とのように Sheehan 症候群 test に反応せず insulin test に反応する例を認め た. 逆に metopirone に正常反応, insulin 低血糖 に対し不良な反応を示した腺腫例はない事を報 告し, この事から metopirone test は視床下部一下 垂体の障害に最も鋭敏に反応し, 軽度の下垂体予備 能の低下を見出すのに最も適しており,一方, insにおいて，なお下垂体一副腎皮質系機能が幾分保持 されている例もあることは興味ある事実である．視 床下部一下垂体一性腺系において，LHRH負荷試験 で，LHの反応が FSH の反応に比較して低い反応を 示した例が2例あった. Distiller ら゙は甲状腺機能 低下の婦人で, LHRH負荷后, LHがFSHに比へて 
Table 4 Endocrine function studies

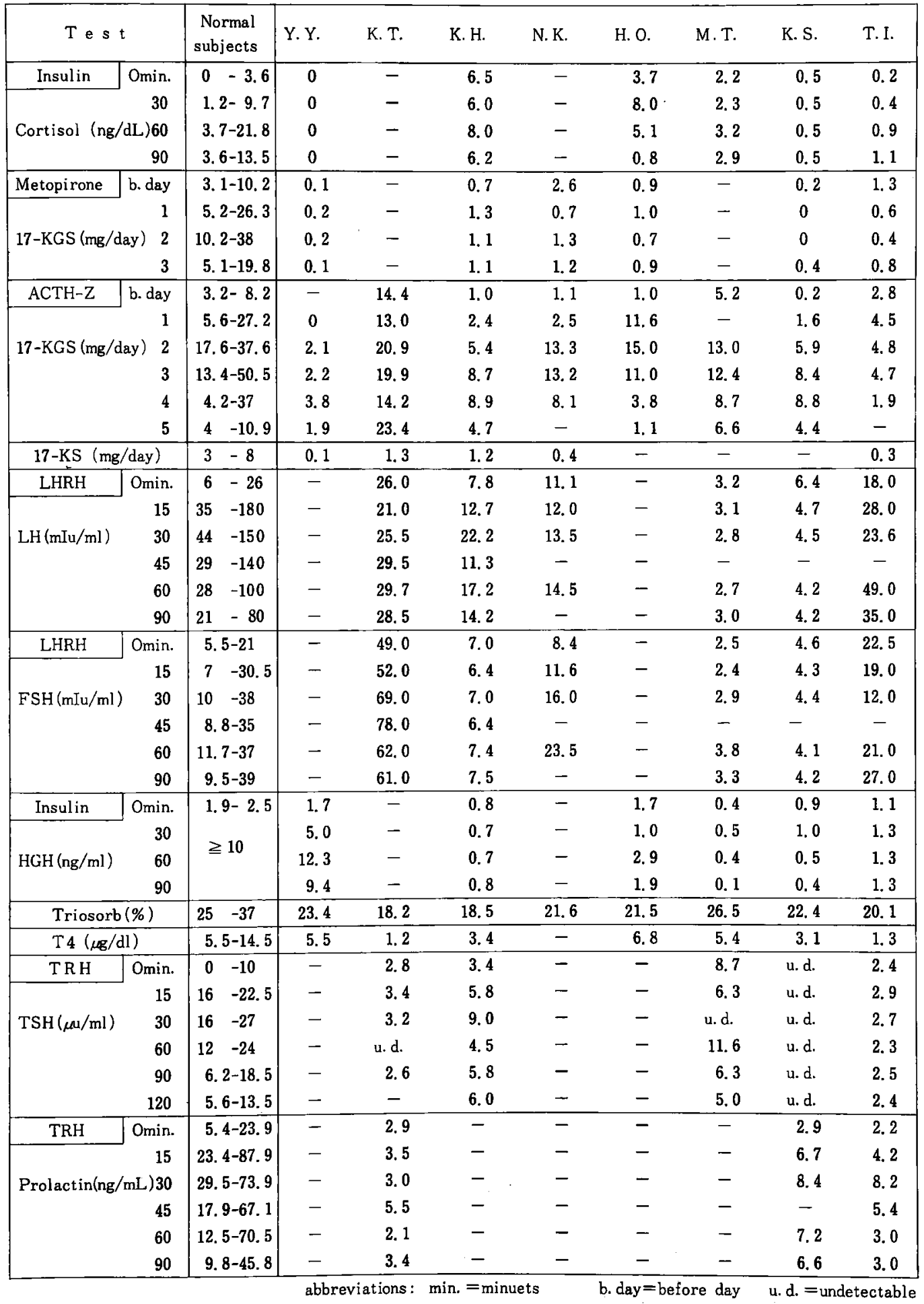




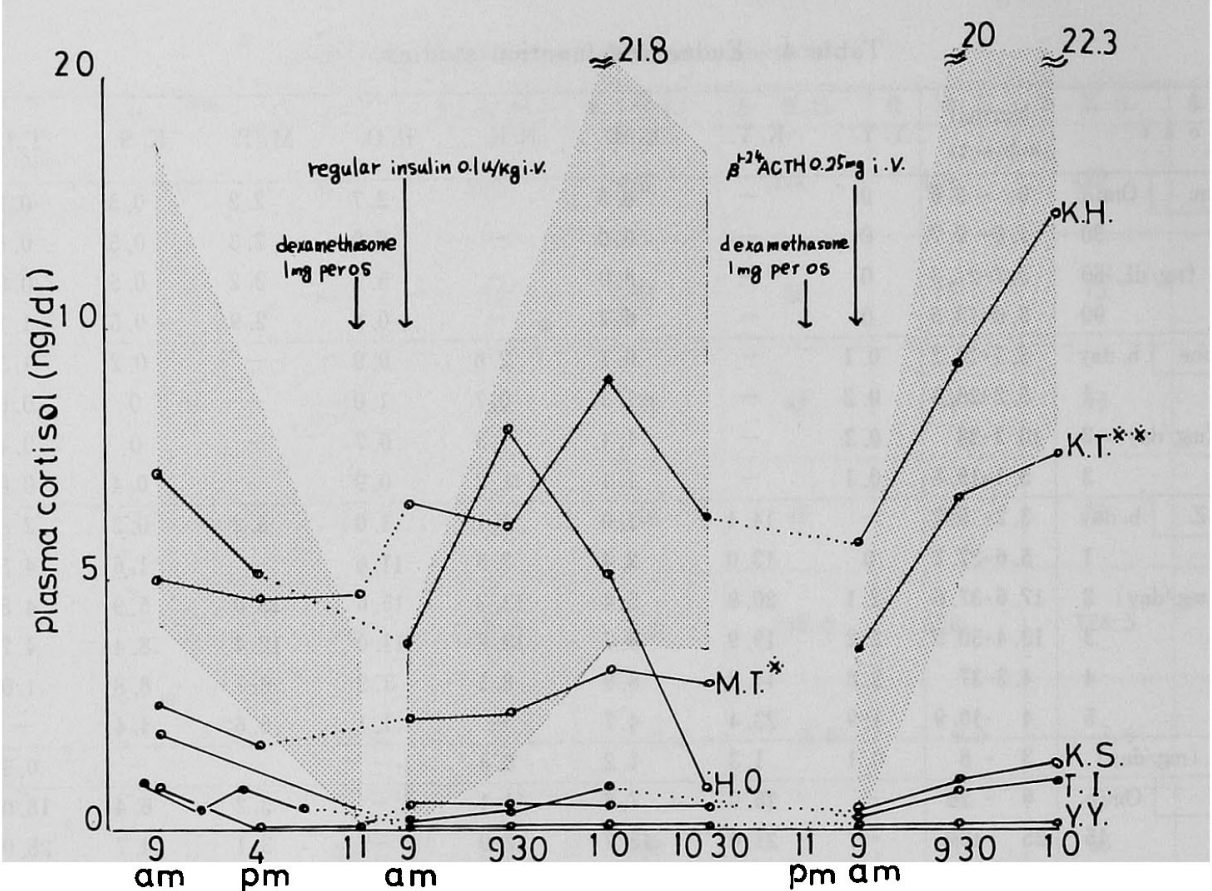

Fig. 1 Plasma cortisol levels to short hypothalamo-hypophyseoadrenocortical function test

※ $10 \mathrm{mg}$ of hydrocortis one is given to M.T.

※30mg of pulv, thyroid. and $80 \mathrm{mg}$ of hydrocortisone is given to K.T.

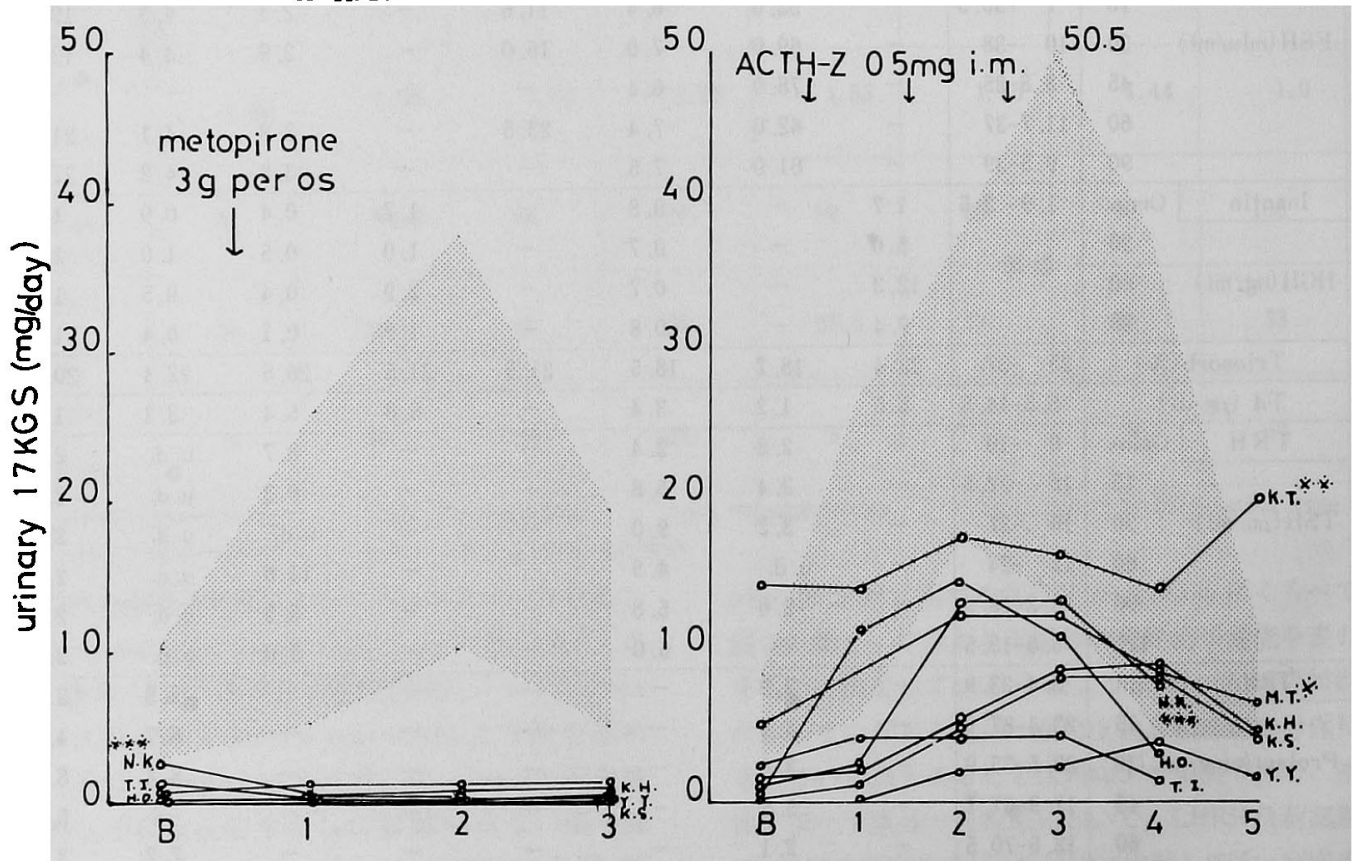

Fig. 2 Urinary 17KGS response to metopirone and ACTH $-\mathrm{Z}$ test ※ $10 \mathrm{mg}$ of hydrocortisone is given to $\mathrm{M}$. $T$.

$※ ※ 30 \mathrm{mg}$ of pluv. thyroid. and $80 \mathrm{mg}$ of hydrocortisone is given to K.T. $※ ※ ※ 30 \mathrm{mg}$ of pulv. thyroid. is given to N.K. 


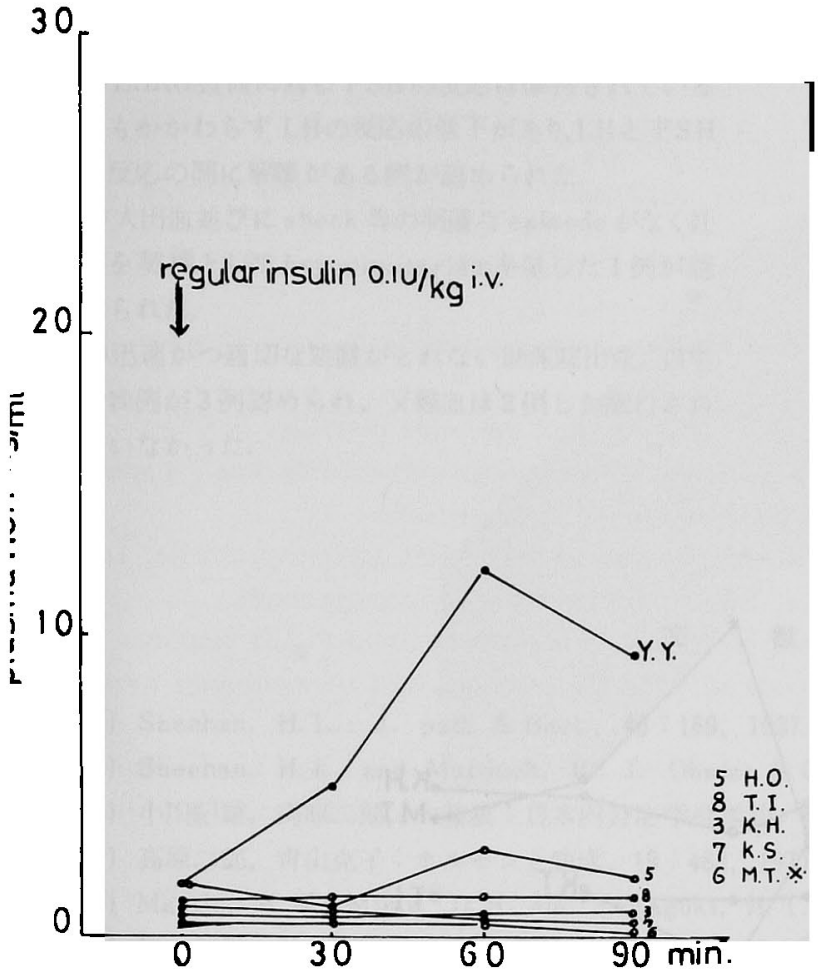

Fig. 3 Plasma HGH response to insulin induced hypoglycemia

※ $10 \mathrm{mg}$ of hydrocortisone is given to M.T.

反応が低下する事を報告し，甲状腺機能低下が，乙 の現象に関与しているととを示陖した. しかし，N.K. 例では，甲状腺末が投与されているにもかかわらず LH と FSH の反応の間に解離が認められた. 尚, K. T. 例でFSHの基礎值並びに反応の高値は，原因 不明ではあるが卵柴の菱縮が関与しているものと 思われる.下垂体一性腺系においてもその機能が維 持されている例があるととも注目すべきととである. 視床下部一下垂体一甲状腺系では，M.T. 例で血中 $T_{1}$ 亚びに $T_{3}-R S U$ 值が正常下界に維持されていた。 TRH負荷での血獎 TSH が幾分増加反応が認められ た事が維持につながると思われる. 種々の視床下部 ホルモン負荷により，8例のうち2例が panhypopituitarism, 残 り 6 例は, selective hypopituitarismを呈している事が判明した。すすでに, Wilson, Sheehan:' Schneeberg ${ }^{101}$ は, 壊死坚が狭い範用の場 合，不完全な下垂体機能低下症を呈するととを報告 している，最近の報告でも Haddockら"11 は50例の Sheehan症候群のうち86\%は panhypopituitarismで, 残り $14 \%$ はselective hypopituitarismであったと
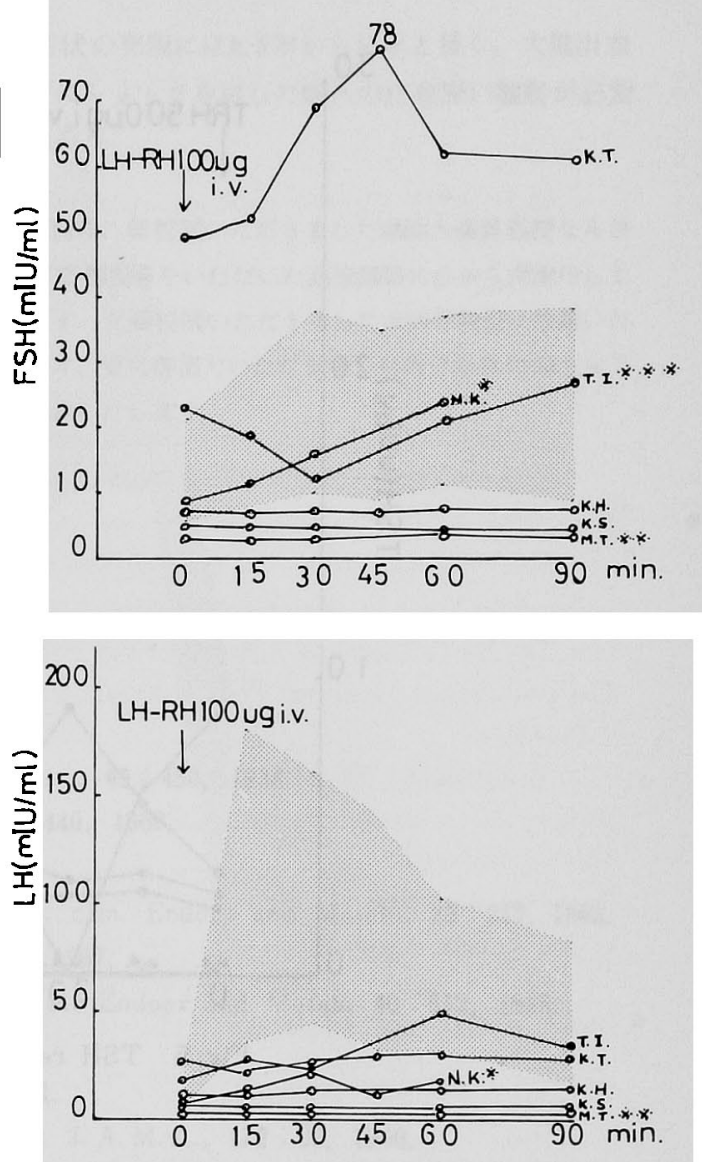

Fig. $4 \mathrm{LH}$ and FSH response to $100 \mu \mathrm{g}$ LH RH i.v.

$※ 10 \mathrm{mg}$ of hydrocortisone and $40 \mathrm{mg}$ of pulv. thyroid. is given to N.K.

※ $10 \mathrm{mg}$ of hydrocortisone is given to M.T.

$※ ※ \circledast 30 \mathrm{mg}$ of pulv. thyroid is given to T.I.

述べている，又，青野ら ${ }^{121}$ も8例の Sheehan 症候群 を報告しているが, selective hppopituitarismが はとんどであったとしている．Rabkinら ${ }^{131}$ は下垂体 ホルモンの脱落の順序は, 成長ホルモン, Gonadotropine, TSH, ACTH の順序で障害され, 順次臨 床症状か婊われてくる事を報告しているが，Israel，“ Sheehan," Schneeberg ${ }^{101}$ は Sheehan症候群では必 ずしもこの順序で下垂体ホルモンは脱落するのでは なく，多様性があることを述べているが，てれは著 者の結果と一致している 大出血后, 出産の経験を

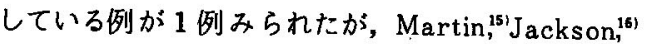




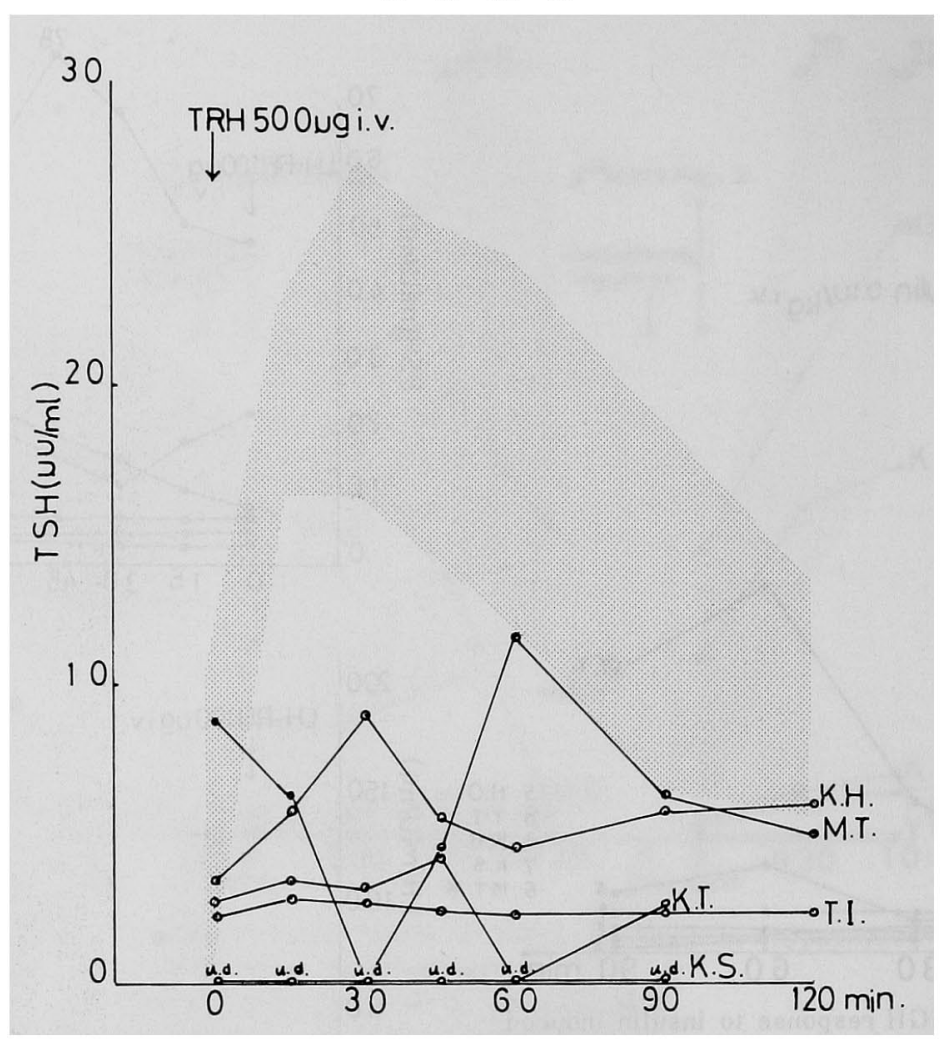

Fig. 5 TSH response to $500 \mu \mathrm{g}$ TRHi.v.

Koplin ${ }^{17}$ ら b Sheehan 症候群の娃娠例をすでに報告 はしている．乙の例では LHRH負荷でFSHの反応 はよく，LHの反応との間に解盛が認められた。分 婏時に大出血並びに shockがないにもかかわらず下 垂体機能低下をきたした1例（Y.Y.）を経験した がこの事は興味ある事実である.すでにPurnel1 ${ }^{191} ら$ も同様な症例を報告していろが，てれらの症例では 分婏を契機としていかなる機序で下垂体機能低下が 惹起したかは不明てある。一般的に Sheehan 症候群 の発症原因に分婏時の環境を指摘されている. Rajasuiya ${ }^{191}$ の報告では Sheehan 症候群の患者の50\% 以上が自宅で分婏を行っており，又，Haddockの報 告 ${ }^{11}$ も本症の $58 \%$ は自宅分婏であったと報告してい ろ. 著者の例においても6 例中 3 例が大量出血立章 びに, shockに対して迅速かつ適切な処置がとれ ないと思われる助産院又は自宅分婏であったととか らも，分婏時の環境は Sheehan 症候群患者の発生予 防のために考えなければならない課題であろう. Sheehan 症候群においては症状発現まで年数が長いこと が知られている. Haddockの報告"'では診断までの 期間は早くて 5 年, 遅くて 25 年で平均 10.5 年と経過
していた. 著者の例でも1.5年から11年, 平均6.5年 経過して診断されている. この理由として種々のこ とが考えられるが, 症状発現が遅いのは，残存下垂 体細胞の機能が徐々に低下してくろためか, 症状は 発現してもそれに気付かないととによるものと思わ れる. 今后, 出産時大量出血並び Shock を呈した 婦人には長い目で注意を向ける必要があると思われ た.

$$
\text { VI とめ }
$$

Sheehan 症候群 8 例について, 病楚, 症状, 一般臨 床血液検查並びに各種下垂体分泌予備機能について 比較検討をし下記の結果をえた。

(1) Sheehan 症候群の 8 例中 2 例は panhypopituitarismの状態であったが，6例ではselective hypopituitarismの状態であった. 予想に反して性腺系機 能が保持されている症例が多かった. 下垂体ホルモ ンの脱落の順序は一定の順序がみられず, 多様性で あった.

(2) metopirone 負荷に対して尿中 17-KGS, 值は反応 せず, insulin負荷に対し軽度ではあろが血漿 cor- 
tisal の反応が認められた症例が 2 例認められた. (3) LHRH負荷に対し FSH の反応は保持されている にもかかわらずLHの反応の低下があり,LHと FSH の反応の間に解離がある例か認められた。

(4)大出血並びに shock 等の明確な episode がなく妊 娠を契機として hypopituitarismを呈した 1 例が認 められた。

(5)迅速かつ適切な好置がとれない助産院出産, 自宅 分婏例が 3 例認められ, 又輸血は 2 例しか施行され ていなかった。
(6)症状の発現には1.5年から11年と長く，大量出血 並びにショックを呈した婦人の注意深い観察が必要 であろう.

御指導，御校閲いただきました恩師大藤冥教授ならび に直接御指導をいただいた高原講師に心から深謝申し上 げます，又御校閲いただきました太田助教授に感謝いだ します．更に御協力いただきました内分汹班の諸先生方 に感謝いたします。

\section{文献}

1) Sheehan, H. L.: J. path \& Bact., $45: 189,1937$.

2) Sheehan, H. L. and Murdoch, R: J. Obstet \& Gynec., 45:456, 1938.

3) 小川紀婎, 高原二郎, 大藤真：日本内分化学会雑誌, 45:440, 1969.

4) 高原二郎, 青山克子：ホルモンと臨床, $19: 483,1971$.

5) Martin, M. M.; Mintz, D. H. and Tawaguki, H. T.: J. clin. Endocr and Metab., 23:242, 1963.

6) 勝木司馬之助, 西田聖幸：日本内分泌学会雑誌, $43 ： 785,1967$.

7) Distiller, L. A., Sagel, J. and Morley, J.E.: J. clin. Endocr and Metab. 40:512, 1975.

8) Wilson, L. A.: Lancet, $1: 715,1954$.

9) Sheehan, H. L.: Proc. Roy. Soc. Med. $54: 43,1961$.

10) Schneeberg, N. G., Perloff, W. H. and Israel, S. L.: J. A. M. A., $172: 20,1960$.

11) Haddock, L., Vega, L. A., Aguiló, F. and Rodrigrez, O.: Hopkins Med. J., 131:80, 1972.

12）青野敏博, 吉田多加子, 倉智敬一：臨床科学, $10 ： 24,1974$.

13) Rabkin, M. T. and Fantz, A. G. Ann. Intern. Med., 64:1197, 1966.

14) Israel, S. L.: J. A. M. A., 148: 189, 1952.

15) Martin J.E., MacDonald P. C. and Koplin N. M.: New England J. Med., 282 : 425, 1970.

16) Jackson I. M. D., Whyte W. G. and Garrey M. M. : J. clin. End., 29:315, 1969.

17) Koplin, R. S., Rosen, R, Brennen, J. L. and Gorden, C. G.: New york State J. Med., 72 : $1157,1972$.

18) Purnell: Mayo clinic proceedings, $39: 391,1964$.

19) Rajasuiya, K.: Ceylon Medical Journal, 16:3, 1971. 


\section{Endocrinological study on Sheehan's syndrome \\ Katsushi AsAOKa}

The Third Department of Internal Medicine, Okayama University Medical School

(Director : Prof. Tadashi Ofuji)

The clinical history, laboratory data, and hypothalamic-pituitary-axis were investigated in 8 patients with Sheehan's syndrome.

2 patients had panhypopituitarism while 6 patients had selective pituitary deficiencies.

Hypothalamic-pituitary-adrenal-axis in 2 patients with Sheehan's syndrome was impaired when the response to metopirone, but not to insulin-induced hypoglycemia.

The interpretation of this difference is complicated in secondary hypothyroidism, and better preserved in the response to metopirone than to insulin-induced-hypoglycemia.

The imbalance of LH and FSH response to LHRH in 2 cases (a blunted LH response in the presence of normal FSH response) may account for the complication of secondary hypothyroidism.

The variety of Sheehan's syndrome was observed, for example that one case without history of postpartum hemorrhage or shock, and others with pregnancy after onset of Sheehan's syndrome.

The duration of illness at the time of diagnosis ranged from 1.5 years to 11 years with an average of 6.5 years.

In the future, a follow-up investigation of women with the history of postpartum hemorrhage or shock is necessary. 